\title{
Choroidal Metastasis as an Unusual Initial Presentation of Transitional Cell Carcinoma of the Kidney
}

\author{
Jamal Khader ${ }^{a}$ Sara Mheid $^{\mathrm{a}} \quad$ Fawzi AbuHijla $^{\mathrm{a}} \quad$ Nadi AlKarmi $^{\mathrm{b}}$ \\ Yacoub Yousef ${ }^{c}$ Yazan Othman ${ }^{\mathrm{d}}$ \\ a Department of Radiation Oncology, King Hussein Cancer Center, Amman, Jordan; \\ ${ }^{b}$ Department of Diagnostic Radiology, King Hussein Cancer Center, Amman, Jordan; \\ ${ }^{c}$ Department of Surgery/Ophthalmology, King Hussein Cancer Center, Amman, Jordan; \\ ${ }^{\mathrm{d}}$ Department of Pathology and Laboratory Medicine, King Hussein Cancer Center, \\ Amman, Jordan
}

\section{Keywords}

Choroid $\cdot$ Transitional cell carcinoma $\cdot$ Cancer $\cdot$ Metastasis

\begin{abstract}
Metastases of transitional cell carcinoma (TCC) of the renal pelvis to the eye is a very rare event, as only one previous case has been described in the literature. We present a patient with choroidal metastasis secondary to TCC of the renal pelvis, with a review of the relevant literature. A 61-year-old male presented with sudden-onset loss of vision of the left eye. Upon evaluation and assessment, the patient was found to have unilateral choroidal metastasis secondary to TCC of the renal pelvis. He is currently on palliative chemotherapy with carboplatin and gemcitabine. External beam radiation therapy is a common mode of treatment and will be considered accordingly.

(C) 2016The Author(s) Published by S. Karger AG, Basel
\end{abstract}

\section{Introduction}

Metastasis of transitional cell carcinoma (TCC) of the renal pelvis to the eye is a very rare event and has only been reported in one case in the literature [1]. Once diagnosed, these 


\section{Case Reports in Oncology}

Khader et al.: Choroidal Metastasis as an Unusual Initial Presentation of Transitional Cell Carcinoma of the Kidney

cases usually show widespread metastases and carry a very poor prognosis [2]. We present a case report of a male patient with unilateral choroidal metastasis secondary to TCC of the renal pelvis. Review of the relevant literature will be addressed to highlight the involvement of the choroid in cases of metastatic disease, the unusual presentation of TCC, diagnostic methods, and the various therapeutic modalities used to treat these cases.

\section{Case Report}

A 61-year-old male, who has a history of congestive heart failure, is a nonsmoker, and has no significant family history of malignancies, presented to the ophthalmology clinic with sudden-onset loss of vision of the left eye associated with intermittent left eye pain, relieved by analgesics. Ophthalmic evaluation revealed a visual acuity of 20/40 in the right eye and $20 / 400$ in the left eye. Slit-lamp examination revealed a normal anterior chamber, except for bilateral cataracts. Funduscopic examination of the left eye showed an amelanotic macular choroidal lesion associated with inferior exudative retinal detachment (Fig. 1a). Funduscopic examination of the right eye was unremarkable. A B-scan ocular ultrasound showed a domeshaped, 2.8-mm choroid thickening with variable internal reflectivity, associated with inferior exudative retinal detachment (Fig. 1b). Optical coherence tomography revealed subretinal fluid. Fluorescein fundus angiography revealed early choroid blockage (Fig. 1c) and late leakage associated with hot spots at tumor margin. All of these clinical features are suggestive of the clinical diagnosis of left choroidal metastasis.

Physical examination of the patient also revealed multiple suspicious chest wall nodules. In search for a primary malignancy, imaging studies were done, which revealed multiple pulmonary and liver metastasis, subcutaneous metastasis, multiple lymphadenopathies, and left renal upper pole mass (Fig. 2). CT-guided left renal mass biopsy and ultrasound-guided biopsy of the left chest wall subcutaneous mass were performed. The histopathological examination revealed tumor consistent with transitional cell carcinoma in both biopsies. The tumor cells are positive for CK7, CK5/6, GATA3, and PAX8. They are negative for CK20, PAX2, TTF-1, synaphopysin, and S100 (Fig. 3).

The patient was started on palliative chemotherapy with carboplatin and gemcitabine. Restaging images will be done following cycle 3 of chemotherapy. External beam radiation therapy (EBRT) is a common mode of treatment [3] and will be considered if there is no improvement of visual symptoms with chemotherapy.

\section{Discussion}

Choroidal metastasis is the most common intraocular malignancy, due to its rich vascular supply and high oxygen concentration $[4,5]$. It is often secondary to breast cancer and lung cancer. Less common primary cancers include the thyroid, prostate, kidney, testicles, pancreas, ovary, and liver [6]. Rarely is it seen in cases of TCC, as there have only been 5 previous reports in the literature involving choroidal metastasis, 3 from tumors involving the bladder, and 2 from other parts of the urinary tract [7].

Choroidal metastasis is commonly associated with disseminated disease and, unfortunately, carries a very poor prognosis [2]. TCC usually metastasizes to the regional lymph nodes $(78 \%)$, liver $(38 \%)$, lung $(36 \%)$, bone $(27 \%)$, adrenal gland $(21 \%)$, and intestine 
(13\%) [8]. The heart, brain, kidney, spleen, pancreas, meninges, uterus, ovaries, prostate, and testes have been reported as unusual sites of presentation of TCC [8].

Clinically, patients with choroidal metastasis typically present with blurred vision (81\%). Other less common clinical presentations include flashes (5\%) and floaters (5\%) [9]. Diagnosis is based on clinical findings, which are typically seen as yellow, plateau-shaped lesions associated with subretinal detachment [10]. A-scan and B-scan ultrasonography show irregular internal reflectivity and a solid plateau-shaped mass, respectively. Fluorescein fundus angiography typically shows mottled hypofluorescence in early stage and leakage in late stage [11]. Further studies are usually carried out in search for a primary tumor.

The treatment of choroidal metastasis should be individually tailored, taking into consideration the patient's systemic state, disease activity, and the presence of visual symptoms. Its aim is palliation, to improve the quality of life of the patient and to restore or maintain visual function [12]. Local therapeutic regimens include EBRT, plaque radiotherapy, and complete enucleation for painful, blind eyes $[13,14]$. EBRT delivered at a dose of 40 Gy over 20 fractions was effective in improving and maintaining vision in patients with choroidal metastasis $[15,16]$. In cases of widespread metastases, systemic chemotherapy alone or in combination with local therapy is an accepted therapeutic option. In patients with choroidal metastasis alone, local therapy has been reported to be safe, maintaining visual functions without the systemic side effects of chemotherapy [14].

\section{Conclusion}

Choroidal metastasis related to TCC of the renal pelvis is an extremely rare event and is associated with widespread disease and a very poor prognosis. Systemic chemotherapy with carboplatin and gemcitabine is a palliative treatment option for this patient. EBRT offers local palliation and will be considered according to the patient's visual response to chemotherapy.

\section{Statement of Ethics}

Patient consent was obtained. All authors reviewed and approved the manuscript.

\section{Disclosure Statement}

All authors declare no competing interests.

\section{References}

1 Atta HR: Presumed metastatic transitional cell carcinoma of the choroids. Br J Ophthalmol 1983;67:830-833.

-2 Kattan J, Droz JP, Boutan-Laroze A, et al: Choroid metastasis in a case of urothelial carcinoma metastatic from the bladder (in French). Prog Urol 1991;1:466-469.

-3 Rudoler SB, Corn BW, Shields CL, De Potter P, Hyslop T, Shields JA, et al: External beam irradiation for choroid metastases: identification of factors predisposing to long-term sequelae. Int J Radiat Oncol Biol Phys 1997;38:251-256.

4 Ferry AP, Font RL: Carcinoma metastatic to the eye and orbit. A clinicopathological study of 227 cases. Arch Ophthalmol 1974;92:276-286. 


\section{Case Reports in Oncology}

\begin{tabular}{l|l}
\hline Case Rep Oncol 2016;9:672-678 \\
\hline DOI: $10.1159 / 000452329$ & $\begin{array}{l}\text { (c) 2016The Author(s). Published by S. Karger AG, Basel } \\
\text { www.karger.com/cro }\end{array}$ \\
\hline
\end{tabular}

Khader et al.: Choroidal Metastasis as an Unusual Initial Presentation of Transitional Cell Carcinoma of the Kidney

5 Avram AM, Gielczyk R, Su L, Vine AK, Sisson JC: Choroidal and skin metastases from papillary thyroid cancer: case and a review of the literature. J Clin Endocrinol Metab 2004;89:5303-5307.

6 Nabi G, Dadeya S, Dogra PN, Lal H: Eye metastasis form urothelial tumours. Int Urol Nephrol 2002;34:51-54.

-7 Hugkulstone CE, Winder S, Sokal M: Bilateral orbital metastases from transitional cell carcinoma of the bladder. Eye 1994;8:580-582.

$\rightarrow 8$ Babaian RJ, Johnson DE, Llamas L, Ayala AG: Metastases from transitional cell carcinoma of urinary bladder. Urology 1980;16:142-144.

9 Besic N, Luznik Z: Choroidal and orbital metastases from thyroid cancer. Thyroid 2013;23:543-551.

$\checkmark 10$ Shields CL, Shields JA, Gross NE, et al: Survey of 520 eyes with uveal metastases. Ophthalmology 1997;104:1265-1276.

11 Zhang HR, Ma ZZ, Feng Y, Guo T: Clinical characteristics of choroidal metastasis. Zhonghua Yan Ke Za Zhi 2009;45:301-308.

12 Asteriou C, Konstantinou D, Kleontas A, et al: Blurred vision due to choroidal metastasis as the first manifestation of lung cancer: a case report. World J Surg Oncol 2010;8:2.

13 Arepalli S, Kaliki S, Shields CL: Choroidal metastases: origin, features, and therapy. Indian J Ophthalmol 2015;63:122-127.

14 Amer R, Pe'er J, Chowers I, Anteby I: Treatment options in the management of choroidal metastases. Ophthalmologica 2004;218:372-377.

15 Rudoler SB, Shields CL, Corn BW, De Potter P, Hyslop T, Curran WJ Jr, Shields JA: Functional vision is improved in the majority of patients treated with external-beam radiotherapy for choroid metastases: a multivariate analysis of 188 patients. J Clin Oncol 1997;15:1244-1251.

16 Wiegel T, Bottke D, Kreusel KM, Schmidt S, Bornfeld N, Foerster MH, Hinkelbein W; German Cancer Society: External beam radiotherapy of choroidal metastases - final results of a prospective study of the German Cancer Society (ARO 95-08). Radiother Oncol 2002;64:13-18. 


\section{Case Reports in Oncology}

\begin{tabular}{l|l}
\hline Case Rep Oncol 2016;9:672-678 \\
\hline DOI: 10.1159/000452329 & $\begin{array}{l}\text { C 2016The Author(s). Published by S. Karger AG, Basel } \\
\text { www.karger.com/cro }\end{array}$ \\
\hline
\end{tabular}

Khader et al.: Choroidal Metastasis as an Unusual Initial Presentation of Transitional Cell Carcinoma of the Kidney
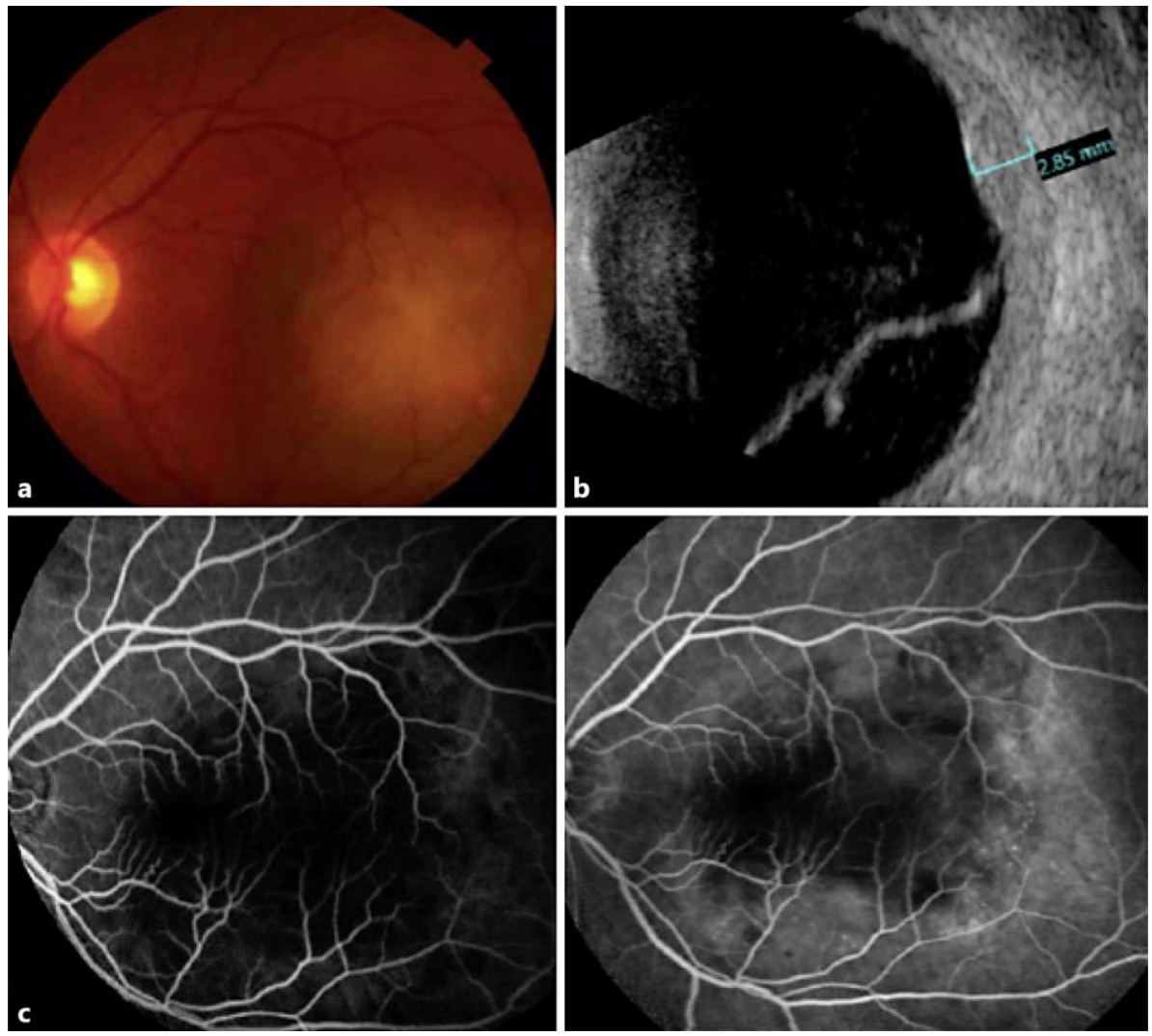

Fig. 1. a Color fundus photograph of the left eye showing macular amelanotic choroidal lesion. b B-scan ultrasonography showed choroid thickening $(2.8 \mathrm{~mm})$ associated with inferior exudative retinal detachment. c Fluorescein fundus angiograph showed early choroid blockage and late leakage associated with hot spots at tumor margin. 


\section{Case Reports in Oncology}

\begin{tabular}{l|l}
\hline Case Rep Oncol 2016;9:672-678 \\
\hline DOI: 10.1159/000452329 & $\begin{array}{l}\text { C 2016The Author(s). Published by S. Karger AG, Basel } \\
\text { www.karger.com/cro }\end{array}$ \\
\hline
\end{tabular}

Khader et al.: Choroidal Metastasis as an Unusual Initial Presentation of Transitional Cell Carcinoma of the Kidney
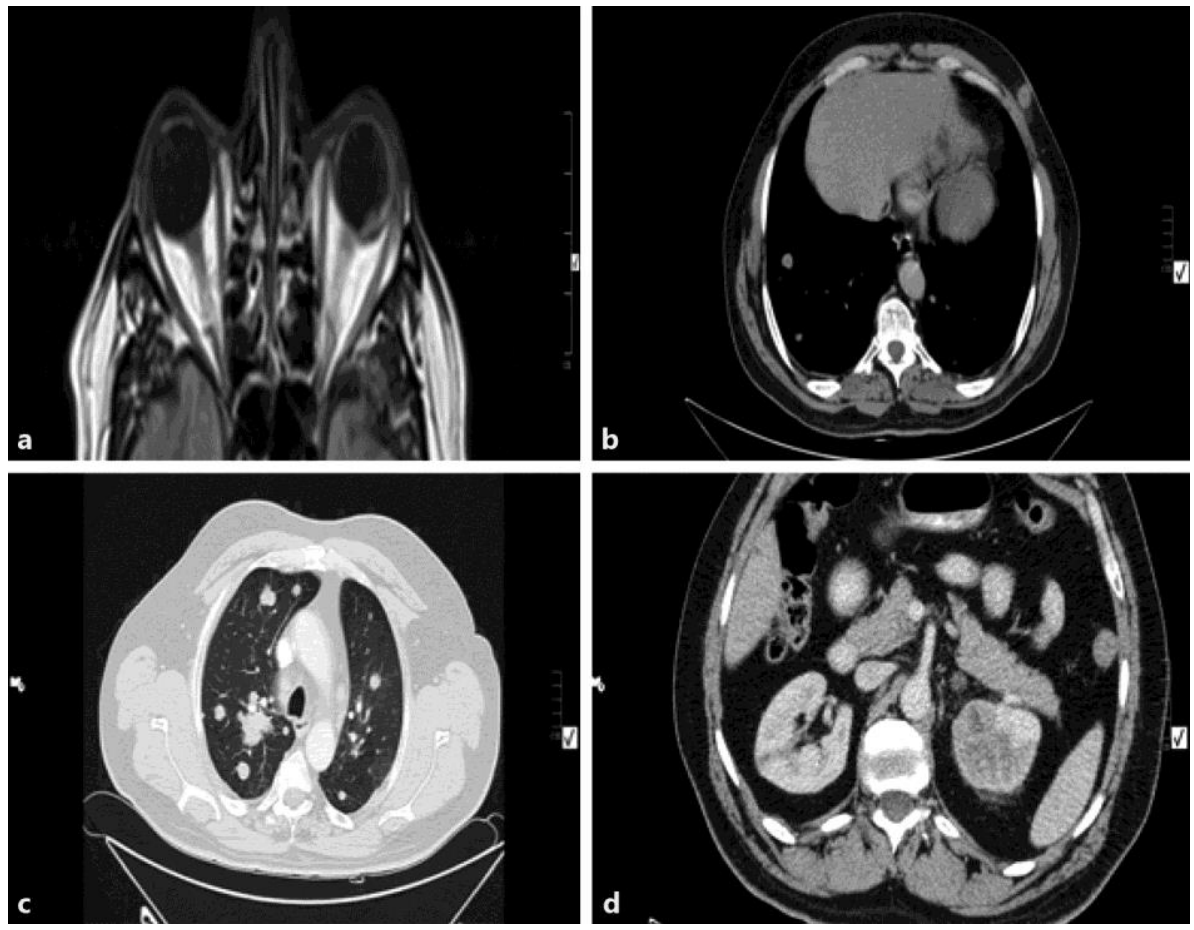

Fig. 2. a Head MRI axial FLAIR sequence showing a left eye choroid lesion. b Subcutaneous soft tissue nodule in the chest wall measuring $1.5 \mathrm{~cm}$. $\mathbf{c}$ Widespread pulmonary metastasis. $\mathbf{d}$ Left upper pole renal mass with progressive enhancement measuring almost $4 \times 5 \mathrm{~cm}$ and $4.5 \mathrm{~cm}$ craniocaudally. 


\section{Case Reports in Oncology}

\begin{tabular}{|c|c|}
\hline Case Rep Oncol 2016;9:67 & \\
\hline DOI: 10.1159/000452329 & $\begin{array}{l}\text { (c) 2016The Author(s). Published by S. Karger AG, Basel } \\
\text { www.karger.com/cro }\end{array}$ \\
\hline
\end{tabular}

Khader et al: Choroidal Metastasis as an Unusual Initial Presentation of Transitional Cell Carcinoma of the Kidney
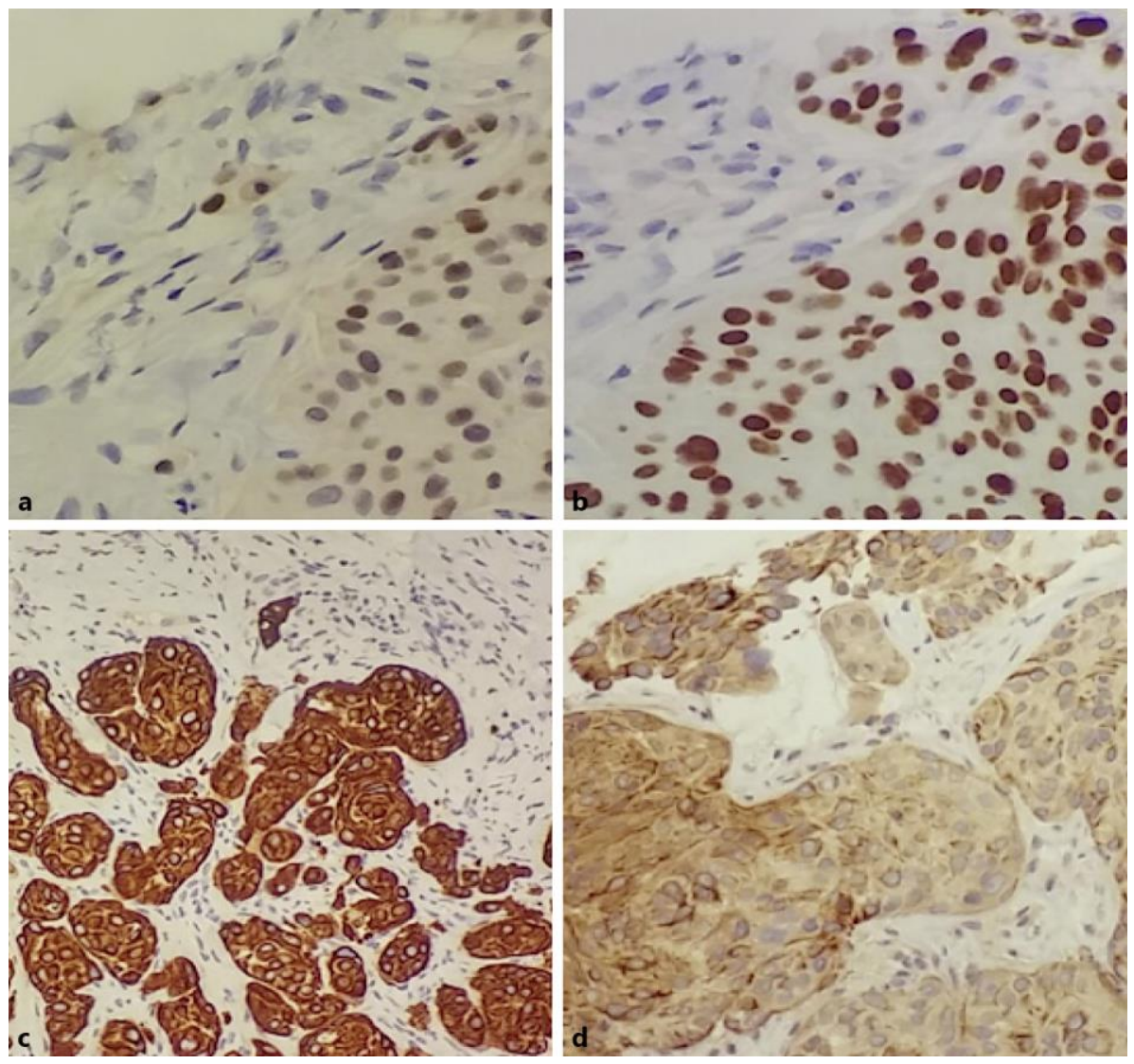

Fig. 3. Microscopic examination of the left renal mass and chest wall subcutaneous mass showing carcinoma consistent with transitional cell carcinoma. The tumor cells stain positive for PAX8 (a), GATA3 (b), cytokeratin 7 (c), and cytokeratin 56 (d). 